\title{
Focal Duration
}

National Cancer Institute

\section{Source}

National Cancer Institute. Focal Duration. NCI Thesaurus. Code C93568.

The period of time in which the entity, activity, event or result is held to be true. 